\title{
Examining the Self-Efficacy among Social Workers at Special Education Schools: A Comparative Study between $M$ ales and Females
}

\section{Mohamed Abdelhakim Khalaf (PhD)}

Assistant Professor, Casework Department Higher Institution of Social Work, Banha

\section{Ehab Hamed Ali (PhD)}

Associate Professor at Individuals and Families Department

Faculty of Social Work- Helwan University- Egypt 



\section{Examining the Self-Efficacy among Social Workers at Special Education Schools: A Comparative Study between Males and Females}

\section{Abstract}

The concept of self-efficacy has received great attention over the course of more than 35 years. It has been studied extensively since Albert Pandora introduced the term in 1986. He referred to selfefficacy as one of the basic components in the human personality as well as a major builder in the performance of the human behavior.

This study aims to determining the degree of self-efficacy of social workers at the schools of special education. and determining the degree of efficacy and perseverance, self-confidence, initiation, and knowledge access of social workers at these schools. The study is applied on 35 social workers at 16 different schools of special education in Qalyubia Governorate. The results show that basedstatistical differences do exist between the degrees average of male and female social workers at special education schools for the disabled on the scale of self-efficacy regarding efficacy, perseverance, selfconfidence, and initiation. The total results are in favor of the male social workers. On the other hand, there are no based-statistical differences between the degrees average of male and female social workers for the knowledge access.

KEYWORDS: Self-Efficacy, Social Worker, Special Education Schools

\section{Introduction}

The education of children with disabilities and those of hard conditions is a main challenge for the achievement of the aims of Education for All, which were approved in the World Forum for All, Dakar/Senegal, April 2000 in which education was confirmed to be one of the basic needs for humans. Providing the right of education is one of the main aims of the UNESCO mission where the right of education has to be attached with the education of good quality for all (UNESCO, 2014, p. 2).

Special education schools aim at raising, learning, and qualifying children with special educational needs from all categories. They also aim at training them to acquire appropriate skills according to their different capabilities and abilities through studied plans and special programs in order to help them reach the best level and prepare them for public life and integration in society (El-Sayed, 2016, p.158). 
Special needs students receive education according to the special education programs, which are based on the philosophy that the disabled were deprived from enjoying their life. Accordingly, their humanity has to be achieved through learning and training them to become useful members for themselves, their families, and their societies as well. (National Center for Educational Research and Development, 2008, p. 13).

The social worker is responsible for professional practice within its different social work settings, of which the field of special education is the most important. He/ She is also considered the tool through which the aims of practice are achieved by the commitment to its philosophy, principles, and scientific methods. Consequently, he/she contributes with other professionals to achieve the desired development in society. Moreover, the personality of the social worker plays an important role in the performance of his professional work because the social work is still characterized by the technical (skill) nature, which depends on his performance on the personality of the social worker himself/herself. (Hussein, 2004, p. 2689)

Farchi (2014) indicated that self-efficacy has been widely discussed in social work literature and has recently been used to assess the outcomes of social work education, in specific areas of professional practice, for social work (Farchi., Cohen \& Mosek, 2014). Bandura (1986) defined self-efficacy as those beliefs that refer to "people's judgments of their capabilities to organize and execute courses of actions required for attaining designated types of performances." (Bandura, 1986, p. 391)

Self-efficacy refers to the basic belief in one's ability to deal with functional challenges successfully for performing desired behaviors and controlling events that affect one's life. Therefore, the essence of self-efficacy is the basic belief of people in their ability to make desirable influences through their own actions. (Bandura, 1997, 2001; Benight \& Bandura, 2004)

Simmons et al. (2017) explained the importance of self-efficacy in teaching and practicing social work. Students need to believe in their ability to perform social work tasks. When social work students lack self-efficacy, they will realize that specific social work tasks are more difficult than they actually are. This may lead to anxiety which, in turn, can contribute to reducing motivation and avoiding the required tasks. On the other hand, highly qualified students may deal with 
challenging tasks with a high level of composure. (Simmons, Fisher, Barnard, \& Allen, 2017).

It can be said that social workers, who have a strong sense of selfefficacy, may be more likely to set higher goals and maintain commitment to achieve them. Alternatively, it can be inferred that social workers who lack self-efficacy may be less willing and able to provide a variety of professional interventions with clients. (Springer \& Schimmel, 2015)

\section{Literature Review}

Zanbar (2020) indicated that there are some factors which help in enhancing self-efficacy. These factors are internal factors such as selfesteem, proficiency, and hope. Three external factors help to enhance self-efficacy. They are called individual interactions with the environment. They are social and psychological support that the individual receives from individuals around him, in addition to social competence and participation in community life. (Zanbar \& Nouman, 2020)

Bandura (1997) stated four sources of self-efficacy: mastery experiences, vicarious experiences, social persuasions, and physiological and affective states(Ooi, Wan Jaafar, \& Baba, 2019; van Rooij, Fokkens-Bruinsma, \& Goedhart, 2019).

Researchers, unanimously, indicated that mastery experience has the most powerful influence on a person's sense of efficacy (Ulenski, Gill, \& Kelley, 2019). Springer (2016) referred to four sources of general self-efficacy to better understand the development of social worker self-efficacy, engagement in role plays (performance), modeling (vicarious learning), and gaining opportunities to receive positive feedback (verbal persuasion). Self-efficacy may be enhanced or derived through performance accomplishments, vicarious experiences, verbal persuasions, and emotional arousals (Bandura, 1977).

The attitude of the individuals towards their known efficacy helps them to continue accomplishing their tasks until they become important parts of their lives. It resembles a co-factor in encouraging them to persevere and achieve progress and excellence in their achievement and tasks (Nayef, 2012, p. 12). This may correspond to the study of Bonett (1994) as it displayed a positive relationship between general self-efficacy on one hand and the professional efficacy in addition to the professional compatibility on the other one. Therefore, the self-efficacy of social workers is generally very 
important, especially for those who work in special education schools or with the disabled people. This is what the current research focuses on.

There are many researches in the literature of social work that addressed the issue of self-efficacy and its role in improving professional practice with clients in social work. These researches include the study of Carter et al. (2018) study that was concerned with assessing self-efficacy and preparing social work students for practice for following simulated instruction. The results of that study indicated that students have achieved high levels in all indicators of selfefficacy (Carter et al., 2018).

Another study was Simmons et al. (2017) that attempted exploring self-efficacy among entry-level and advanced BSW students. The results of that study indicated that only advanced students obtain significantly higher degrees of self-efficacy beliefs than beginner students do. The results also indicated that increased mastery experiences in the social work method might help students to develop confidence in their ability to practice as professional social workers (Simmons et al., 2017).

Simons et al. (2016) indicated that there are a set of factors which likely increases the self-efficacy of practice for social workers. Among these factors are the lengths of long experience in practice, the size of younger cases, additional training, the exposure to older clients with complex needs, the monitoring of the effective clinical practices of the colleagues, the support from colleagues or supervisors, group or individual supervision, and methods for managing stress at work. (Simons, An. \& Bonifas, 2016)

The study of MacAteer et al. (2016), which dealt with the awareness of social workers working in the field of mental health of self-efficacy, showed the presence of strong negative correlations between the organizational climate and role stressors. There was also a negative correlation of moderate significance between self-efficacy and role ambiguity. (MacAteer., Manktelow, \& Fitzsimons, 2016)

The study of Hong et al. (2016) attempted to assess the selfefficacy measure of Korean American caregivers. The results of that study showed that the CSE-K is a reliable and valid measurement to assess caregiver self-efficacy for Korean American caregivers (Hong, Kim, \& Casado, 2016). The study of Williford (2015) demonstrated the importance of self-efficacy among social workers as one of the 
important indicators in the success or failure of efforts to prevent and interfere with bullying among students (Williford, 2015).

The study of Collins (2013) demonstrated the importance of selfefficacy as an alternative psychological approach for social workers and social work students with stressful shocks in the UK. The study indicated that concepts of feeling coherence, self- efficacy, and a sense of control are important psychological concepts in helping social workers and social work students to become more flexible in their approach. Self-efficacy is about beliefs and confidence in one's ability to do tasks. (Collins, 2013)

Danis, Dong \& Anderson (2007) also indicated that there is a relationship between the self-efficacy of the practice with the victims of any crime and the orientation that the social worker earned by continuing education and training. The results of that study also showed the role self-efficacy plays for practitioners in dealing with victims' problems and the skills needed to work with them (Danis, Dong, \&, Anderson, 2007). Parker (2006) indicated that participation in practical training helps to enhance the self-efficacy of social work students, especially with regard to carrying out many tasks such as role-playing, teamwork, and communication.

Golia \& Pedrazza (2014) stated that the received self-efficacy is interested in people's beliefs that they are able to succeed in certain conditions and can play a pivotal role in meeting targets, tasks, and challenges. That research introduced the structure of a self-efficacy scale prepared for social workers. (Golia \& Pedrazza, 2014, p. 58).

The previous foreign studies focused mainly on the knowledge of selfefficacy, whether among social work students or social workers, and its relationship to their professional competence with different groups emphasizing the importance of self-efficacy and its effect on the professional performance of social workers.

As such, the purpose of the present study was to investigate the selfefficacy of social workers at special education schools in a sample in Egypt.

\section{Objectives of the Study:}

The aim of this study is to:

1- Examine the self-efficacy among male and female social workers in special education schools in Egypt.

2- Identify the self-efficacy for the social workers in special education schools with its dimensions (efficacy, perseverance, self-confidence, initiation, and knowledge access) 


\section{Study Hypotheses:}

1- The social workers' lack of self-efficacy in special education schools with its dimensions (efficacy, perseverance, selfconfidence, initiation, and knowledge access)

2- The Existence of statistically-based differences between male and female social workers in special education schools on the scale of self-efficacy and its dimensions (efficacy, perseverance, self-confidence, initiation, and knowledge access)

\section{Method}

1-Type of Study: the current study is a part of a cross-sectional study designed to assess the Social Workers' self-efficacy in special education schools in Egypt.

2- Study Methodology: the researchers relied on the comprehensive social survey method regarding cases of social workers who work in special education schools within Qalyubiyya Governorate.

3- Study population: the researchers made a comprehensive count of (35) social workers working in special education schools affiliated with Qalyubiyya Governorate. The research was applied to (16) schools from the special education schools in Qalyubiyya Governorate within the period from January 2018 until March 2018.

4- Study Tools: while designing the scale, the two researchers reviewed previous studies, researches, and theoretical writings which focused on the self-efficacy of social workers. The scale was designed in two parts as follows:

Part One: includes demographic data related to (gender, age, and marital status).

Part Two: includes (45) phrases to measure the self-efficacy of social workers distributed over four dimensions.

The researchers considered designing the scale as follows:

A- Determining the type of data to be obtained.

B- Putting phrases that are closely related to the aim of the study.

C- Using easy statements, clear content, and confirmation during testing the scale.

D- Terms are consistent with the educational and cultural levels of social workers. 


\section{Validity and Reliability of the Self-Efficacy Measure for Social Workers}

A. Validity: the researchers relied on two types of Validity, namely:

1- The content validity (the apparent): it includes the proportions of the arbitrators' agreement on the paragraphs of the scale. The measure of social workers' self-efficacy was presented to a number of professors of sociology, social work, and psychology. Field practice that provided that arbitration takes place within:

1. The extent to which the paragraph relates to each dimension of the study.

2. In terms of the wording of the paragraph.

3. In terms of content.

Accordingly, the dimensions of the scale have been modified, some of the paragraphs have been modified, and the paragraphs with an agreed-upon ratio less than $85 \% \mathrm{~h}$ يave been deleted. The number of paragraphs of the scale has reached (41) paragraphs considering measuring the self-efficacy of social workers distributed over four dimensions: (persistence, self-confidence, initiation, and knowledge). The agreement percentage has been calculated according to the (Getman) equation.

1- Validity of the Internal (Global) Consistency: the researcher calculated the internal consistency of the questionnaire paragraphs on a collective sample of 20 individual samples.

Table (1) shows the internal consistency among the variables of the self-efficacy scale for the social workers and the total degree.

\begin{tabular}{|c|l|c|c|}
\hline $\mathbf{N}$ & \multicolumn{1}{|c|}{$\begin{array}{c}\text { Dimensions of the } \\
\text { Scale }\end{array}$} & $\begin{array}{c}\text { Correlation Coefficient } \\
\text { with the Total Score }\end{array}$ & $\begin{array}{c}\text { Significance } \\
\text { Level }\end{array}$ \\
\hline 1 & $\begin{array}{l}\text { Persistence and } \\
\text { perseverance }\end{array}$ & 0.718 & $* *$ \\
\hline 2 & Self-confidence & 0.848 & $* *$ \\
\hline 3 & Initiation & 0.789 & $* *$ \\
\hline 4 & Knowledge Access & 0.716 & $* *$ \\
\hline
\end{tabular}

** Significance at $\mathbf{P}$ value $(0.00)$ (0.05)

* Significance at $\mathbf{P}$ value

It is obvious from the previous table that the dimensions of the self-efficacy measure of social workers have a statistical significance at the level (0.01). This gives an indication of the high coherence of internal consistency. It indicates high and sufficient sincerity that can be trusted in the application of the current study. 
B - Reliability: the researchers used two methods to ensure the reliability of the scale:

1. Alpha-Cronbach: the researchers applied the scale to a sample specifying the psychometric properties then, it was re-applied to the same sample after an interval time of (15) days (two weeks between the first and second application). The researchers, then, calculated the reliability of the self-efficacy scale for social workers through using Alpha Cronbach's Reliability Factor. The following table shows the scale reliability factor:

Table (2) shows the persistent results using (Alpha Cronbach) to measure the self-efficacy of social workers.

\begin{tabular}{|c|c|c|}
\hline $\mathbf{N}$ & Dimension & $\begin{array}{c}\text { Alpha- Cronbach } \\
\text { Coefficient }\end{array}$ \\
\hline 1 & $\begin{array}{c}\text { Self-Efficacy Measurement reliability for } \\
\text { Social Workers as a Whole }\end{array}$ & 0.921 \\
\hline
\end{tabular}

** Significance at $\mathbf{P}$ value $(0.00) \quad *$ Significance at $\mathbf{P}$ value $(0.05)$

The previous table shows that the self-efficacy measure for social workers is statistically high. It enables us to rely on the finding tools. 2. Midterm Fragmentation: the researchers used the (SpearmanBrown) equation for midterm segmentation where the expressions of each variable were divided into two halves. The first section included the values obtained from the responses of the individual paragraphs and the second section includes the values that express the marital paragraphs. The test results came as follows. Table (3) shows persistent results using the (Spearman-Brown) equation for the midterm segmentation of the self-efficacy scale for social workers.

\begin{tabular}{|c|c|c|}
\hline $\mathbf{N}$ & Dimension & Spearman Brown Equation \\
\hline 1 & $\begin{array}{c}\text { Self-Efficacy Measurement reliability } \\
\text { for Social Workers as a Whole }\end{array}$ & 0.942 \\
\hline
\end{tabular}

** Significance at $\mathbf{P}$ value $(\mathbf{0 . 0 0 )} \quad$ * Significance at $\mathbf{P}$ value $(0.05)$

It is clear from the previous table that most of the reliability coefficients of the variables have a high degree of reliability. Thus, its results can be relied upon and the tool has become finalized.

\section{5- The Statistical Tools}

The researchers unloaded and analyzed data from the two measures through the Statistical Analysis Program (SPSS- 20). The following statistical tests were use:

\section{Percentages and Repeats}

Arithmetic mean: the researchers relied on the following criteria to judge the level of social workers' self-efficacy in special education 
schools according to the arithmetic means obtained by the respondents, as follows:

- From (1) to less than (1.67) was sorted as a weak level.

- From (1.67) to less than (2.34) was sorted as an intermediate level.

- From (2.34) to less than (3) was sorted as a high level.

\section{Standard Deviation}

-Reliability coefficient (Alpha- Cronbach).

-Brown-Spearman Split-Half.

-The T-Test.

\section{Findings}

Table (4): Demographic Data

\begin{tabular}{|l|c|c|}
\hline \multicolumn{1}{|c|}{ Variables } & Frequency & \% \\
\hline 1- Gender & 21 & 60 \\
\hline Male & 14 & 40 \\
\hline Female & 35 & 100 \\
\hline Total & \multicolumn{2}{|l|}{} \\
\hline 2- Age & 11.4 \\
\hline $\begin{array}{l}\text { From 20 - to less than 30 } \\
\text { years }\end{array}$ & 4 & 51.4 \\
\hline 30- to less than 40 years & 18 & 31.4 \\
\hline $\begin{array}{l}\text { From 40 to less than 50 } \\
\text { years }\end{array}$ & 11 & 5.7 \\
\hline 50 years or more & 2 & 100 \\
\hline Total & 35 & 38.14 \\
\hline Mean & \multicolumn{2}{|l|}{} \\
\hline SD & 3 & 8.658 \\
\hline 3- Social status & 29 & 2.9 \\
\hline Unmarried & 1 & 5.7 \\
\hline Married & 2 & 100 \\
\hline Divorced & 35 & \\
\hline Widower & \multicolumn{2}{|l|}{} \\
\hline Total & \multicolumn{2}{|c|}{} \\
\hline
\end{tabular}

The demographic data of the study population showed that the majority of the study population were about males. It reached $(60 \%)$ when compared to females (40\%). Their average age was (38.14) years. The population of students, in the age group, was targeted between (SD 0.758; 30- less than 40 Years) (51.4\%), and those whose marital status was 'married' reached $(82.9 \%)$. The lowest percentage was for divorced as $(2.9 \%)$. 


\begin{tabular}{|c|c|}
\hline Egyptian Journal of Social Work (EJSW) & http://ejsw.journals.ekb.eg \\
\hline Print ISSN: 2356-9204 Online ISSN: 2356-9212 & Vol 10, Issue 1, June 2020 \\
\hline
\end{tabular}

Table (5): The Degree of Efficacy and Perseverance for Social Workers

\begin{tabular}{|c|l|c|c|c|c|}
\hline N & \multicolumn{1}{|c|}{$\begin{array}{l}\text { The Degree of Efficacy and } \\
\text { Perseverance }\end{array}$} & Mean & SD & \% & Ranking \\
\hline 1 & $\begin{array}{l}\text { I always seek to implement plans } \\
\text { that help me work }\end{array}$ & 2.54 & 0.561 & 84.76 & 1 \\
\hline 2 & $\begin{array}{l}\text { I seek to achieve my goals even if I } \\
\text { fail more than once. }\end{array}$ & 2.51 & 0.612 & 83.81 & 2 \\
\hline 3 & $\begin{array}{l}\text { Do not leave tasks and jobs before } \\
\text { completing them in an integrated } \\
\text { manner. }\end{array}$ & 2.46 & 0.741 & 81.90 & 3 \\
\hline 4 & $\begin{array}{l}\text { I work hard to find the right ways } \\
\text { to work. }\end{array}$ & 2.37 & 0.770 & 79.05 & 4 \\
\hline 5 & $\begin{array}{l}\text { Be patient when exposed to } \\
\text { difficult and complex situations. }\end{array}$ & 2.31 & 0.796 & 77.14 & 5 \\
\hline 6 & $\begin{array}{l}\text { I have the ability and the } \\
\text { determination to always help me } \\
\text { get things done. }\end{array}$ & 2.31 & 0.676 & 77.14 & 5 \\
\hline 7 & $\begin{array}{l}\text { I like work that includes challenge } \\
\text { and competition. }\end{array}$ & 2.23 & 0.770 & 74.29 & 7 \\
\hline 8 & $\begin{array}{l}\text { I can handle the troubles and } \\
\text { difficulties whatever how big they } \\
\text { are and take time and effort. }\end{array}$ & 2.26 & 0.780 & 75.24 & 6 \\
\hline 9 & $\begin{array}{l}\text { I don't give up achieving my } \\
\text { positive goals in work }\end{array}$ & 2.20 & 0.759 & 73.33 & 8 \\
\hline 10 & $\begin{array}{l}\text { I seek to learn new things even if } \\
\text { they are difficult. }\end{array}$ & 2.17 & 0.785 & 72.38 & 9 \\
\hline & TOTAL & 23.37 & 2.891 & 77.90 & - \\
\hline
\end{tabular}

It is clear from the previous table that there is a degree of efficacy and perseverance for social workers working in special education schools for the disabled. It came in the first order "I always seek to implement the plans that help me work" with a rate of $(84.76 \%)$ and an average of (2.54), while the standard deviation was (0.561). Then, in the second order "I seek to achieve my goals even if I fail more than once" by a rate of $(73.81 \%)$ and an average of $(2.51)$. The standard deviation, hence, was (0.612), while came last "I seek to learn new things even if they were difficult" by a rate of $(72.38 \%)$ and an average of (2.17), while the standard deviation was (0.785). 
Table (6): The Degree of Self-Confidence for Social Workers Working in Schools for Disabled Special Education

\begin{tabular}{|c|c|c|c|c|c|}
\hline $\mathbf{N}$ & Self-Confidence Degree & Mean & SD & $\%$ & Ranking \\
\hline 1 & $\begin{array}{l}\text { I feel confident in dealing with } \\
\text { them. }\end{array}$ & 2.77 & 0.598 & 92.38 & 1 \\
\hline 2 & $\begin{array}{l}\text { I accept criticism directed at me } \\
\text { without sensitivity or anger. }\end{array}$ & 2.71 & 0.519 & 90.48 & 2 \\
\hline 3 & $\begin{array}{l}\text { I'm good at dealing with sudden } \\
\text { events and situations. }\end{array}$ & 2.66 & 0.591 & 88.57 & 3 \\
\hline 4 & $\begin{array}{l}\text { I don't lose control of my behavior } \\
\text { when I get angry. }\end{array}$ & 2.63 & 0.646 & 87.62 & 4 \\
\hline 5 & $\begin{array}{l}\text { I can successfully cope with } \\
\text { stressful life events. }\end{array}$ & 2.60 & 0.604 & 86.67 & 5 \\
\hline 6 & I am a calm and balanced person. & 2.51 & 0.658 & 83.81 & 8 \\
\hline 7 & $\begin{array}{l}\text { Most of my thoughts and beliefs } \\
\text { are rational and logical. }\end{array}$ & 2.63 & 0.646 & 87.62 & 4 \\
\hline 8 & $\begin{array}{l}\text { I can control myself for a long } \\
\text { time. }\end{array}$ & 2.60 & 0.604 & 86.67 & 5 \\
\hline 9 & $\begin{array}{l}\text { I always speak in a clear and strong } \\
\text { manner without fluctuations or } \\
\text { clinging. }\end{array}$ & 2.71 & 0.572 & 90.48 & 2 \\
\hline 10 & $\begin{array}{l}\text { I always look at the one whom I'm } \\
\text { taking to with confidence and } \\
\text { balance without shame. }\end{array}$ & 2.57 & 0.558 & 85.71 & 6 \\
\hline 11 & $\begin{array}{l}\text { My words always show positive } \\
\text { optimistic signs away from stress } \\
\text { and anxiety. }\end{array}$ & 2.49 & 0.658 & 82.86 & 9 \\
\hline 12 & $\begin{array}{l}\text { I keep my smile most of the time } \\
\text { even in the most difficult } \\
\text { conditions. }\end{array}$ & 2.54 & 0.611 & 84.76 & 7 \\
\hline & TOTAL & 31.43 & 4.017 & 87.30 & - \\
\hline
\end{tabular}

It was clear from the previous table that social workers working in the disabled special education schools have a high degree of selfconfidence as it came in the first order (I feel confident in dealing with them) with a percentage of (92.38\%) and an average of (2.77) while the standard deviation was (0.598). In the second order (I accept the criticism directed to me without sensitivity or anger, I always speak in a clear and strong way without fluctuation or 
clinging (90.48\%) and average (2.71) while, the standard deviation was $(0.519 ; 0.572)$. The last arrangement was (my words always show positive optimistic signs apart from stress and anxiety $(84.76 \%)$ and average (2.54), while the standard deviation was (0.611). These findings may be consistent with the study of Rose-Grau et al. (2001) whose results indicated that an individual's beliefs about his/her selfefficacy play an important role in reducing stress and fatigue.

Table (7): Degree of Initiation for Social Workers Working in Special Education Schools for the Disabled

\begin{tabular}{|c|c|c|c|c|c|}
\hline $\mathbf{N}$ & Initiation Degree & Mean & SD & $\%$ & Ranking \\
\hline 1 & $\begin{array}{l}\text { I am persuading others to my } \\
\text { view. }\end{array}$ & 1.86 & 0.845 & 61.90 & 1 \\
\hline 2 & $\begin{array}{l}\text { I interfere to solve the } \\
\text { differences between my } \\
\text { workmates. }\end{array}$ & 1.46 & 0.657 & 48.57 & 7 \\
\hline 3 & $\begin{array}{l}\text { I always seek to learn new } \\
\text { things. }\end{array}$ & 1.80 & 0.759 & 60.00 & 2 \\
\hline 4 & $\begin{array}{l}\text { I take the initiative to help my } \\
\text { colleagues in difficult } \\
\text { situations. }\end{array}$ & 1.74 & 0.852 & 58.10 & 4 \\
\hline 5 & $\begin{array}{l}\text { I take the initiative to know } \\
\text { and chat with new colleagues. }\end{array}$ & 1.66 & 0.802 & 55.24 & 5 \\
\hline 6 & $\begin{array}{l}\text { I always like to share my } \\
\text { colleagues with their } \\
\text { activities. }\end{array}$ & 1.51 & 0.702 & 50.48 & 6 \\
\hline 7 & $\begin{array}{l}\text { I always initiate group } \\
\text { activities to work as one } \\
\text { collaborating team. }\end{array}$ & 1.66 & 0.802 & 55.24 & 5 \\
\hline 8 & $\begin{array}{l}\text { I take the initiative to } \\
\text { apologize and reconcile if I } \\
\text { make a mistake against } \\
\text { someone. }\end{array}$ & 1.37 & 0.598 & 45.71 & 8 \\
\hline 9 & $\begin{array}{l}\text { I always initiate proposals } \\
\text { and plans for work } \\
\text { development. }\end{array}$ & 1.74 & 0.886 & 58.10 & 4 \\
\hline 10 & $\begin{array}{l}\text { I always take the } \\
\text { responsibility of leading the } \\
\text { team and take responsibility. }\end{array}$ & 1.77 & 0.877 & 59.05 & 3 \\
\hline & TOTAL & 16.57 & 4.978 & 55.24 & - \\
\hline
\end{tabular}


The previous table reveals the degree of initiation of social workers working in schools for special education for the disabled. It came in the first order (I am persuading others to my view) with a percentage $(61.90 \%)$ and an average (1.86) while the standard deviation was (0.854). In the second order, came (I always seek to learn new things with a percentage $(60 \%)$ and an average (1.80) while, the standard deviation was (0.759). It came in the last order (I take the initiative to apologize and reconcile if I make a mistake against someone) with $(45.71 \%)$ and an average (1.37) while, the deviation was Benchmark (0.589).

Table (8): The Degree of Cognitive Knowledge of Social Workers Working in Schools of Special Education for the Disabled

\begin{tabular}{|c|l|c|c|c|c|}
\hline $\mathbf{N}$ & Cognitive Knowledge Degree & Mean & SD & \% & Ranking \\
\hline $\mathbf{1}$ & $\begin{array}{l}\text { I have enough information on } \\
\text { my work field. }\end{array}$ & 1.83 & 0.747 & 60.95 & 1 \\
\hline $\mathbf{2}$ & $\begin{array}{l}\text { I always like to have a look on } \\
\text { new and updated studies of } \\
\text { social sciences. }\end{array}$ & 1.63 & 0.731 & 54.29 & 4 \\
\hline $\mathbf{3}$ & $\begin{array}{l}\text { I always want to know the } \\
\text { latest models and practical } \\
\text { theories. }\end{array}$ & 1.63 & 0.690 & 54.29 & 4 \\
\hline $\mathbf{4}$ & $\begin{array}{l}\text { I always make a monthly } \\
\text { schedule to read a new book. }\end{array}$ & 1.66 & 0.725 & 55.24 & 3 \\
\hline $\mathbf{5}$ & $\begin{array}{l}\text { I'm always interested in } \\
\text { reading the latest cognitive and } \\
\text { therapeutic methods of } \\
\text { interfering with individuals. }\end{array}$ & 1.69 & 0.718 & 56.19 & 2 \\
\hline $\mathbf{6}$ & $\begin{array}{l}\text { I always rely on internationally } \\
\text { trusted scientific references and } \\
\text { sources. }\end{array}$ & 1.60 & 0.604 & 53.33 & 5 \\
\hline $\mathbf{7}$ & $\begin{array}{l}\text { I tend to rely on cognitive } \\
\text { opinions and ideas that can be } \\
\text { applied. }\end{array}$ & 1.60 & 0.651 & 53.33 & 5 \\
\hline $\mathbf{8}$ & $\begin{array}{l}\text { I'm always interested in analyzing } \\
\text { individuals' problems and } \\
\text { explaining them using modern } \\
\text { scientific knowledge. }\end{array}$ & 1.46 & 0.561 & 48.57 & 7 \\
\hline $\mathbf{9}$ & $\begin{array}{l}\text { I'm interested in modern } \\
\text { knowledge in teaching and } \\
\text { learning in my work field. }\end{array}$ & 1.57 & 0.739 & 52.38 & 6 \\
\hline & \begin{tabular}{l} 
TOTAL \\
\hline
\end{tabular} & 14.66 & 4.419 & 54.29 & - \\
\hline
\end{tabular}


It is clear from the previous table that social workers working in schools of special education for the disabled have a degree of cognitive knowledge. It came in the first order (I have enough information about my work field) with a percentage of $(60.95 \%)$ and an average of (1.83) while, the standard deviation was (0.747). In the second order came (I was always interested in reading the latest cognitive and therapeutic methods of interfering with individuals) with a percentage of (56.19\%) and an average of (1.69) while, the standard deviation was (0.718). In the last order came (I'm always interested in analyzing individuals' problems and explaining them using modern scientific knowledge) with a percentage of $(48.57 \%)$ and an average of (1.46) while, the standard deviation was (.651).

Table (9): A Degree for Social Workers Working in Schools of Special Education for the Disabled on the Total Scale as a Whole

\begin{tabular}{|c|l|c|c|c|c|}
\hline $\mathbf{N}$ & $\begin{array}{c}\text { Dimensions of the } \\
\text { Scale as a Whole }\end{array}$ & Mean & SD & \% & Ranking \\
\hline 1 & $\begin{array}{l}\text { Efficacy and } \\
\text { Perseverance }\end{array}$ & 23.37 & 2.891 & 77.90 & 2 \\
\hline 2 & Self-Confidence & 31.43 & 4.017 & 87.30 & 1 \\
\hline 3 & Initiation & 16.57 & 4.978 & 55.24 & 3 \\
\hline 4 & Knowledge Access & 14.66 & 4.419 & 54.29 & 4 \\
\hline \multicolumn{2}{|r|}{ TOTAL } & 86.03 & 8.042 & 68.68 & - \\
\hline
\end{tabular}

It is clear from the previous table the order of the dimensions of the scale of self-efficacy for social workers working in schools of special education for the disabled. It came in the first order (self-confidence) at $(87.30 \%)$ and an average of (31.43) while, the standard deviation was (4.017). In the second one came (efficacy and persistence) (by $77.90 \%)$ and an average of (23.37) while, the standard deviation was (2.891). In the third order came (initiation) by (55.24\%) and an average of (16.57) with a standard deviation of $(4,978)$. While 'knowledge' came in the last order $(54.29 \%)$ and an average of (14.66) while, the standard deviation was (4.419). 
Table (10) shows the differences between the averages of scores (male and female) regarding social workers working in schools of special education for the disabled on the scale of self-efficacy.

\begin{tabular}{|c|c|c|c|c|c|c|}
\hline $\begin{array}{c}\text { Significance } \\
\text { level }\end{array}$ & $\begin{array}{c}\mathbf{T} \\
\text { value }\end{array}$ & $\begin{array}{c}\text { Freedom } \\
\text { Degree }\end{array}$ & $\begin{array}{l}\text { Standard } \\
\text { Deviation }\end{array}$ & Average & $\begin{array}{c}\text { Social } \\
\text { Workers }\end{array}$ & $\begin{array}{l}\text { The main } \\
\text { variable }\end{array}$ \\
\hline \multirow{2}{*}{$\begin{array}{l}\text { Function at } \\
(0.01) \text { level }\end{array}$} & \multirow{2}{*}{3.096} & \multirow{2}{*}{33} & 2.135 & 24.57 & Males & \multirow{2}{*}{$\begin{array}{l}\text { Efficacy and } \\
\text { perseverance }\end{array}$} \\
\hline & & & 3.180 & 21.57 & Females & \\
\hline \multirow{2}{*}{$\begin{array}{l}\text { Function at } \\
(0.05) \text { level }\end{array}$} & \multirow{2}{*}{2.203} & \multirow{2}{*}{33} & 3.203 & 32.48 & Males & \multirow{2}{*}{$\begin{array}{l}\text { Self- } \\
\text { confidence }\end{array}$} \\
\hline & & & 4.413 & 29.64 & Females & \\
\hline \multirow{2}{*}{$\begin{array}{l}\text { Function at } \\
(0.05) \text { level }\end{array}$} & \multirow{2}{*}{2.365} & \multirow[t]{2}{*}{33} & 3.727 & 17.90 & Males & \multirow{2}{*}{$\begin{array}{l}\text { The } \\
\text { initiation }\end{array}$} \\
\hline & & & 4.027 & 14.71 & Females & \\
\hline \multirow{2}{*}{$\begin{array}{l}\text { Non- } \\
\text { function }\end{array}$} & \multirow{2}{*}{1.199} & \multirow[t]{2}{*}{33} & 4.421 & 15.38 & Males & \multirow{2}{*}{$\begin{array}{l}\text { Knowledge } \\
\text { Access }\end{array}$} \\
\hline & & & 4.345 & 13.57 & Females & \\
\hline \multirow{2}{*}{$\begin{array}{l}\text { Function at } \\
(0.01) \text { level }\end{array}$} & \multirow{2}{*}{4.162} & \multirow[t]{2}{*}{33} & 5.953 & 90.33 & Males & \multirow[t]{2}{*}{ Total scale } \\
\hline & & & 9.485 & 79.50 & Females & \\
\hline
\end{tabular}

Table $(T)$ value at the level of significance $(0.01)=(2.750)$, and at level of significance $(0.05)=(2.042)$

\section{Discussion}

Self-efficacy plays a prominent role in influencing the professional performance of a social worker. This efficacy is shaped in the form of ideas and beliefs about the self-regarding its efficacy. Benz and his colleagues stated that these ideas come between the knowledge and skills of the social worker and his/her actual performance in professional situations with children in special education schools.

The self- efficacy is not just common feelings but, it is an evaluation of the individual for himself/herself for what he/she can do, the extent of his/her perseverance, the amount of the effort he/she exerts, the extent of his/her flexibility in dealing with difficult and complex situations, as well as the amount of his/her resistance to failure. (Benz et al., 1992, p.171)

This study tries to fill the research gap in the studies of social workers self-efficacy in the Egyptian environment, specifically with the disabled children. This study aims at identifying the differences between male and female social workers in special education schools in Egypt upon the scale of self-efficacy. Study results indicate that there are statistically significant differences between the averages of the degrees (male and female) social workers working in special 
education schools for the disabled on the scale of self-efficacy with regard to the dimension of self-efficacy in favor of male social workers.

These differences may be due to the participation of male social workers in more training courses and continuous learning that help them enhance their self-efficacy. Parker (2006) stated that the participation in the practical training help the students of social work enhance their self-efficacy. This is consistent with the study of Khalil (2009) that confirmed the existence of statistically significant differences between the mean scores of the population individuals on the perceived self-efficacy scale attributed to gender in favor of males. Ahn et al. (2012) also referred that students of higher levels were more confident of their abilities in practicing social work than those students who were registering in social work preliminary courses (Ahn, Boykin, Hebert, \& Kulkin, 2012).

The high levels of male self-efficacy may be due to the high level of ambition among male social workers in special education schools in Egypt or due to the preoccupation of female social workers with the family chores rather than the professional tasks.

Self-efficacy is one of the dimensions of self-management as it influences the beliefs of the social worker in his/her ability to solve problems, which increases his motivations to transform these beliefs into realistic behavior. A social worker who has a strong sense of selfefficacy considers the difficult task as a challenge that must be overcome, not a threat that must be avoided and ignored. This point of view makes the social worker busy in his/her work until he/she succeeds and feels satisfaction with his/her work. This is considered one of the most important reasons that encourages the researchers to investigate the level of self-efficacy of social workers in special education schools in Egypt.

The study results indicate that there are statistically significant differences between the averages of the degrees (male and female) social workers working in special education schools for the disabled on the scale of self-efficacy with regard to the dimension of efficacy and perseverance in favor of male social workers.

The results also show that there are significant differences between the average scores of (male and female) social workers working in special education schools for the disabled on the scale of self-efficacy with regard to the dimension of self-confidence in favor of male social workers. 
Moreover, the study results indicate that there are significant differences between the averages of the scores (male and female) social workers working in special education schools for the disabled on the scale of self-efficacy with regard to the dimension of initiation in favor of male social workers.

The findings of the current study show that there are no significant differences between the mean scores of (male and female) social workers working in schools of special education for the disabled on the scale of self-efficacy in relation to the cognitive dimension. This means that they may have the same educational programs in the different educational stages. In Egypt there are 23 institutions for social work education: five schools of social work, 12 high institutes for social work, and 5 middle institutes for social work. The majority of these institutions teach the same social work course syllabus in dealing with the disabled.

On the other hand, the results of Ahn et al. (2012differed from the study results of Semple-Dormer (2013): The State of Self-efficacy among Massachusetts School-based Occupational Therapists. The results of Semple-Dormer's study confirmed that the demographic features and background don't effect on the level of self-efficacy of the study population (Semple-Dormer, 2013).

The results of the study also differed from what was indicated by the study of Al- Raffou (2019) that the self-efficacy of females working in governmental schools in Jordan was higher than that of males (Al-Raffou, 2019).

\section{Study Limitation}

There are clear limitations to this study. Although the study uses a purposive population, the social workers working in special education schools affiliated with Qalyubiyya Governorate, it is inappropriate to generalize the results to all social workers. Samples from different geographical regions may provide different results. Secondly, the questionnaire is self-reported and does not capture the actual practices related to professional requirements. Thirdly, self-reporting measures introduces sources of errors and biases, such as participants consistently choosing high or low ratings.

\section{Implications for Social Work Practice}

Self-efficacy is an estimation from the social worker to his/her own abilities on doing professional effective practice with clients and a judgement on his/her abilities to affect on the clients' problems. According to the great importance of the self-efficacy concept in 
social work, the study recommends the following points. Our findings have useful academic and practical implications, especially for social workers working in special education schools' settings. Thus, we make the following recommendations: (1) Include self-efficacy issues in social work educational curriculums at both the undergraduate, graduate levels and continuous education programs. (2) Creating a series of training courses for social work students in all social work education phases with the purpose of enhancing self-efficacy among social workers in all social work professional setting .(3) Carrying out future studies to identify professional interventions to enhancing the self-efficacy for Practitioners in social work practice settings, and especially in special education schools' settings. (4) Encourage female social workers to enhance their social efficacy by participating in the continuous learning activities and training courses as well as observing the effective clinical practices of male social workers.

\section{Conclusion}

In conclusion, this study investigated the self-efficacy of social workers at special education schools. We found that based-statistical differences do exist between the degrees average of male and female social workers at special education schools for the disabled on the scale of self-efficacy regarding efficacy, perseverance, selfconfidence, and initiation. The total results were in favor of the male social workers. On the other hand, there are no based-statistical differences between the degrees average of male and female social workers for the knowledge access. The study invites researchers to conduct studies concerned with self-efficacy with use of a large representative sample in the future.

\section{Acknowledgments}

The authors thank all participants for their contribution to this study. We also deeply appreciate the assistance of the School of Social Work Dean at the Higher Institute of Social work at Banha in Egypt for her support in conducting this study. The authors would like to acknowledge the contributions of Dr. Dina Sayed's editing services to the English language review of this article. 


\section{References}

Abdel-Razek, Ahmed Hussein (2004): Supervisory Needs to Develop the Professional Performance of Social Workers in the School Field, Manchuria Research for the Seventeenth Scientific Conference, Cairo, Faculty of Social Work, Helwan University, Volume V.

Ahmed, Sayed Mohamed El-Sayed (2016): Societal Dimensions and their Educational Implications for the School Theater in Special Education Schools, Journal of the Faculty of Education (Benha University) - Egypt.

Ahn, B., Boykin, L., Hebert, C., \& Kulkin, H. (2012). Exploring Baccalaureate Social Work Students' Self-Efficacy: Did it Change over Time? Journal of Teaching in Social Work, 32(5), 487-501. doi:10.1080/08841233.2012.724046.

Alice Cartera, et.al (2017):Self-efficacy and quality of life in adults who stutter, Journal of Fluency Disorders 54.

Al-Raffou, Mohamed Ahmed Khalil (2019). The degree of psychological stiffness and its relationship to perceived self-efficacy among teachers of government basic schools in the Tafila Governorate in southern Jordan, Journal of Studies in Educational Sciences, 64 (3), 181-200.

Bandura, a, (1997) self-efficacy: the exercise of control, w. h. Freeman, New York.

Bandura, A. (2002). Social foundations of thought and actions: A social cognitive theory. In D. Marks (Ed.), The health psychology (pp. 94106). Sage.

Benight, C. C., \& Bandura, A. (2004). Social cognitive theory of posttraumatic recovery: The role of perceived self-efficacy. Behaviour Research and Therapy, 42(10), 1129-1148.

Beimers, David, (2016): Legislative Advocacy Days: Building Political SelfEfficacy in Social Work Students., Journal of Policy Practice. OctDec2016, Vol. 15 Issue 4.

Benz, c, bardely, 1, alderman\& flowers (1992), personal teaching efficacy: developmental relation- ships in education, journal of education research, 85(5).

Bonett, R., (1994). Marital states and gender: Impact on careerSelf-efficacy, Journal of counseling and development, 73.

Carter, K., Swanke, J., Stonich, J., Taylor, S., Witzke, M., \& Binetsch, M. (2018). Student Assessment of Self-Efficacy and Practice Readiness Following Simulated Instruction in an Undergraduate Social Work Program. Journal of Teaching in Social Work, 38(1), 28-42.

Central Agency for Public Mobilization and Statistics (2016): Egypt in 2016 Figures International Disability Alliance (2010): Guidance Document, Efficient Use of International Mechanisms to Monitor and Protect the Rights of Persons with Disabilities. 
Collins, S. (2013). Alternative Psychological Approaches for Social Workers and Social Work Students Dealing with Stress in the UK: Sense of Coherence, Challenge Appraisals, Self-Efficacy and Sense of Control. British Journal of Social Work, 45(1), 69-85. doi:10.1093/bjsw/bct103

Danis, F. S., Dong, P. Y., \& Anderson, K. M. (2007). The role of selfefficacy in mediating personal and environmental factors that influence practice with crime victims: Implications for professional development. Professional Development, 10(1), 25-36.

Farchi, M., Cohen, A., \& Mosek, A. (2014). Developing Specific SelfEfficacy and Resilience as First Responders among Students of Social Work and Stress and Trauma Studies. Journal of Teaching in Social Work, 34(2), 129-146.

Hong, M., Kim, K., \& Casado, B. L. (2016). Psychometric evaluation of the Caregiver Self-Efficacy Scale with Korean Americans. Soc Work Health Care, 55(10), 861-873.

Imons, Kelsey, An, Sofiya, Bonifas, Robin (,2016): Professional and practice characteristics associated with self-efficacy in assessment and intervention among social workers in aging, Social Work in Health Care. May-Jun2016, Vol. 55 Issue 5.

Jarwan, Fathi et al. (2013): Students with Special Needs-Introduction to Special Education, Amman, Dar Al-Fikr Publishers.

MacAteer, A., Manktelow, R., \& Fitzsimons, L. (2016). Mental Health Workers' Perception of Role Self-Efficacy and the Organisational Climate Regarding the Ethos of Recovery. British Journal of Social Work, 46(3), 737-755. d.

National Center for Educational Research and Development (2008): Teaching People with Special Needs, Periodical Bulletin, 11.

Ooi, P. B., Wan Jaafar, W. M. B., \& Baba, M. B. (2019). Relationship between sources of counseling self-efficacy and counseling selfefficacy among Malaysian school counselors. The Social Science Journal, 55(3), 376-389.

Parker, J. (2006). Developing perceptions of competence during practice learning. British Journal of Social Work, 36(6), 1017-1036. doi:10.1093/bjsw/bch347.

Semple-Dormer, Y. (2013). The State of Self-efficacy among Massachusetts School-based Occupational Therapists. Journal of Occupational Therapy, Schools, \& Early Intervention, 6(4), 372-387. doi:10.1080/19411243.2013.860770

Silvia Golia, Monica Pedrazza,)2014,(: Assessing the elational competence as the core dimension of social worker's perceived self-ecacy through the Rasch model, Electronic Journal of Applied Statistical Analysis Vol. 7, Issue 1. 
Simmons, C., Fisher, A. K., Barnard, M., \& Allen, S. C. (2017). Exploring Self-Efficacy among Entry-Level and Advanced BSW Students. Journal of Teaching in Social Work, 37(4), 369-384. doi:10.1080/08841233.2017.1324550

Simons, K., An, S., \& Bonifas, R. (2016). Professional and practice characteristics associated with self-efficacy in assessment and intervention among social workers in aging. Soc Work Health Care, 55(5), 362-380. doi:10.1080/00981389.2016.1147514

Springer, S. I. (2016). Examining Predictors of Group Leader Self-Efficacy for Preservice School Counselors. The Journal for Specialists in Group Work, 41(4), 286-311.

Springer, S. I., \& Schimmel, C. J. (2015). Creative Strategies to Foster PreService School Counselor Group Leader Self-Efficacy. The Journal for Specialists in Group Work, 41(1), 2-18.

Ulenski, A., Gill, M. G., \& Kelley, M. J. (2019). Developing and validating the elementary literacy coach self-efficacy survey. The Teacher Educator, 54(3), 225-243.

UNESCO (2014): Educating Children with Disabilities in University Frameworks, Accepting Diversity: A Toolkit to Create UniversityFriendly Environments for Learning Specialized Handbook 3 (Arabic version), UNESCO Regional Office for Education in the Arab States - Beirut.

van Rooij, E. C. M., Fokkens-Bruinsma, M., \& Goedhart, M. (2019). Preparing Science Undergraduates for a Teaching Career: Sources of Their Teacher Self-Efficacy. The Teacher Educator, 54(3), 270-294. doi:10.1080/08878730.2019.1606374

Williford, A. (2015). Intervening in Bullying: Differences across Elementary School Staff Members in Attitudes, Perceptions, and Self-Efficacy Beliefs. Children \& Schools, 37(3), 175-184

Yaqoub, Nayef (2012): Perceived Self-Efficacy and its Relationship to the Motivation for Academic Achievement Among Students of King Khalid University colleges in Bisha, Journal of Educational and Psychological Sciences, Volume 13, No. 3.

Zanbar, L., \& Nouman, H. (2020). Predictors of self-efficacy among residents of low-income neighborhoods: Implications for social work practice. Journal of Social Work, 146801732091150. doi:10.1177/1468017320911503 
